\title{
Responses of Guava Plants to Inoculation with Arbuscular Mycorrhizal Fungi in Soil Infested with Meloidogyne enterolobii
}

\author{
Maryluce Albuquerque da Silva Campos ${ }^{1 *}$, Fábio Sérgio Barbosa da Silva ${ }^{1}$, Adriana Mayumi Yano-Melo ${ }^{2}$, \\ Natoniel Franklin de Melo ${ }^{3}$, Elvira Maria Régis Pedrosa ${ }^{4}$ and Leonor Costa Maia ${ }^{5}$ \\ ${ }^{1}$ UPE (Universidade de Pernambuco) Campus Petrolina, BR 203, Km 2, 56300-000, Petrolina, PE, Brasil \\ ${ }^{2}$ UNIVASF (Fundação Universidade Federal do Vale do São Francisco), Petrolina, PE, Brasil \\ ${ }^{3}$ EMBRAPA SEMI-ÁRIDO (Empresa Brasileira de Pesquisa Agropecuária), Petrolina, PE, Brasil \\ ${ }^{4}$ UFRPE (Universidade Federal Rural de Pernambuco), Recife, PE, Brasil \\ ${ }^{5}$ UFPE (Universidade Federal de Pernambuco), Recife, PE, Brasil
}

(Received on October 16, 2012; Revised on April 8, 2013; Accepted on April 12, 2013)

In the Northeast of Brazil, expansion of guava crops has been impaired by Meloidogyne enterolobii that causes root galls, leaf fall and plant death. Considering the fact that arbuscular mycorrhizal Fungi (AMF) improve plant growth giving protection against damages by plant pathogens, this work was carried out to select AMF efficient to increase production of guava seedlings and their tolerance to $M$. enterolobii. Seedlings of guava were inoculated with 200 spores of Gigaspora albida, Glomus etunicatum or Acaulospora longula and 55 days later with 4,000 eggs of $M$. enterolobii. The interactions between the AMF and $M$. enterolobii were assessed by measuring leaf number, aerial dry biomass, $\mathrm{CO}_{2}$ evolution and arbuscular and total mycorrhizal colonization. In general, plant growth was improved by the treatments with $A$. longula or with $G$ albida. The presence of the nematode decreased arbuscular colonization and increased general enzymatic activity. Higher dehydrogenase activity occurred with the $A$. longula treatment and $\mathrm{CO}_{2}$ evolution was higher in the control with the nematode. More spores and higher production of glomalin-related soil proteins were observed in the treatment with $\boldsymbol{G}$ albida. The numbers of galls, egg masses and eggs were reduced in the presence of $\boldsymbol{A}$. longula. Inoculation with this fungus benefitted plant growth and decreased nematode reproduction.

Keywords : enzymatic activity, glomeromycota, Psidium guajava, root knot

In the lower middle region of the São Francisco Valley, located in the States of Pernambuco and Bahia, Northeast Brazil, characterized by semi-arid climate with mean temper-

\footnotetext{
*Corresponding author.

Phone) $+558738666468, \quad$ FAX) +558738666500

E-mail)marylucecampos@yahoo.com.br
}

ature of $27^{\circ} \mathrm{C}$ and $350-800 \mathrm{~mm}$ annual precipitation, the irrigated areas with fruit crops have shown promising development especially concerning guava (Psidium guajava L.). However, the parasitism of the nematode Meloidogyne enterolobii a sedentary endoparasite which causes root galls, browning of the leaf edge and yellowing of the aerial shoots leads to general defoliation and plant death (Carneiro et al., 2001). This plant pathogen causes high losses and plantation abandonment. One of the promising alternatives for root-knot control could be the use of arbuscular mycorrhizal fungi (AMF) which in association with the plant roots improves nutrient uptake and increase plant development, protecting the host against biotic and abiotic stresses (Maia et al., 2006). Meta analysis performed by Borowicz (2001) based on studies published between 1970 and early 1998 has shown that AMF decrease nematode performance, indicating increased resistance, with this harmful effect being extensive only to sedentary nematodes.

The positive effect of AMF on growth of guava plantlets has been demonstrated (Schiavo and Martins, 2002), as well as interactions of nematode and AMF in different crops. Such interactions depend upon the plant species, the AMF isolate, the nematode involved and the cultivation conditions (Diedhiou et al., 2003; Elsen et al., 2003). In the particular case of Meloidogyne species, the plants associated with AMF can induce decrease in number of root galls and eggs of the nematode, and, as a consequence, growth improvement and development are observed leading to reduction in damages with increase in production (JaizmeVega et al., 1997).

Considering that there are no reports regarding a tripartite interaction including AMF, nematodes and guava plants, the hypothesis that the inoculation with these fungi can reduce the damage caused by $M$. enterolobii was tested. Therefore, the aim of this work was to select AMF efficient in increasing production of guava plantlets and tolerance to 
the guava root-knot nematode.

\section{Materials and Methods}

Soil classified as loamy sand (collected in Petrolina municipality, State of Pernambuco, in the Caatinga biome, close to the Embrapa Semi-arid Experimental Station) was treated with Bromex ${ }^{\circledast}$ (98\% methyl bromide and $2 \%$ chloropicrin) and allowed to rest for 15 days before use. The soil, analyzed at the Embrapa Soil Laboratory, has the following chemical characteristics: $\mathrm{pH} 6.9 ; 23 \mathrm{mg} \mathrm{dm}{ }^{-3}$ of $\mathrm{P} ; 0.69$ $\mathrm{cmol}_{\mathrm{c}} \mathrm{dm}^{-3}$ of K$; 3.9 \mathrm{cmol}_{\mathrm{c}} \mathrm{dm}^{-3}$ of Ca; $0.9 \mathrm{cmol}_{\mathrm{c}} \mathrm{dm}^{-3}$ of $\mathrm{Mg} ; 0.19 \mathrm{cmol}_{\mathrm{c}} \mathrm{dm}^{-3}$ of Na; $12.0 \mathrm{~g} \mathrm{dm}^{-3}$ of organic matter and $6.34 \mathrm{cmol}_{\mathrm{c}} \mathrm{dm}^{-3}$ of cation exchange capacity.

Guava (P. guajava cv. Paluma) plantlets (90 days old rooted cuttings) were acquired from the Brazil Plantlets Company in Petrolina-PE. In the laboratory, the plantlets were removed from the substrate (a mixture of sawdust, vermiculite and guava commercial substrate), and the roots washed with water and transferred to black polyethylene bags with $2 \mathrm{~kg}$ of the aforementioned soil. The inoculum was composed by 200 spores, hyphae and colonized roots of the following AMF: Gigaspora albida N. C. Schenck \& G. S. Sm. (UFPE 01), Glomus etunicatum W. N. Becker \& Gerd. (UFPE 06) or Acaulospora longula Spain \& N. C. Schenck (UFPE 21) produced in a sand + vermiculite substrate and multiplied in association with Panicum miliaceum L., was applied to the rhizosphere of each plant. These plantlets were maintained under greenhouse conditions (average temperature: $27 \pm 2{ }^{\circ} \mathrm{C}$; relative humidity: $75 \%$; luminosity: 250 to $560 \mu \mathrm{mole} / \mathrm{m}^{2} / \mathrm{s}$ ) and 55 days after inoculation with the AMF, received a suspension of 4,000 eggs and juveniles of $M$. enterolobii, extracted following the Hussey and Barker (1973) method. The nematode was obtained from infected guava roots, collected at the Tamba Farm (BR 428, Km 154, Petrolina, PE).

The experiment was conducted using a completely randomized design in factorial scheme with: 4 AMF treatments (inoculated with A. longula, G. albida or G. etunicatum and an uninoculated control) $\times 2$ nematode treatments (presence or absence of M. enterolobii) in 5 replicates. The experimental results were examined 98 days after inoculation with AMF, and the following variables were evaluated: plant height, number of leaves, stem diameter, dry and fresh biomass of the aerial part, fresh root biomass, leaf area, mycorrhizal colonization, AMF spore density, production of glomalin-related soil proteins (GRSP), numbers of galls, egg masses and eggs, total and per gram of root, $\mathrm{CO}_{2}$ evolution, dehydrogenase activity and global soil enzymatic activity.

Dry biomass was obtained after oven drying $\left(60^{\circ} \mathrm{C}\right)$ until constant weight. Leaf area was measured with a $\mathrm{Li} 3100$ device (LI-Cor Inc. Lincoln, Neb., USA). Roots were cleared in $10 \% \mathrm{KOH}$, stained with $0.03 \%$ Chlorazol Black (Brundrett et al., 1984) and the percentage of hyphae, arbuscules and vesicles were evaluated (McGonigle et al., 1990). Spores of AMF were extracted from the soil by wet sieving and centrifugal flotation (Gerdemann and Nicolson, 1963; Jenkins, 1964) and quantified with a stereomicroscope $(40 \times)$. Glomalin-related soil proteins were extracted as described by Wright and Upadhayha (1996) and quantified by the Bradford (1976) method. Nematode eggs were extracted using $1 \mathrm{~cm}$ root fragments immerse in $1 \%$ sodium hypochlorite for 4 minutes in constant shaking (Hussey and Barker, 1973). The counting was made using a light microscope.

Dehydrogenase activity was evaluated by the Casida et al. (1964) method, the $\mathrm{CO}_{2}$ content determined according to Grisi (1978) and general soil enzymatic activity analyzed by fluorescin diacetate hydrolysis (Swisher and Caroll, 1982).

Data were submitted to analysis of variance and the values in percentage (mycorrhizal colonization) and in numbers (AMF spore density, number of galls, egg masses and eggs) were transformed into $\arcsin \mathrm{x} / 100$ and in $\log \mathrm{x}+1$, respectively. For determining statistical significance, mean values were compared by the Tukey test at $5 \%$ probability. The analyses were carried out using Statistica 6.0 software (Statsoft, 1997).

\section{Results}

In plants without the nematode, the number of leaves did not differ between the control (without AMF) and plants inoculated with G. albida and A. longula. However, in the presence of the pathogen, the number of leaves was higher in the treatment with A. longula (Table 1). For dry biomass of the aerial part, differences occurred only in plants inoculated with G. etunicatum which were smaller than those of the other treatments when the pathogen was present (Table 1).

Fresh root biomass was significantly higher in AMF inoculated plants; whereas larger leaf area was observed in plantlets inoculated with A. longula and G. albida. However, only those associated with $A$. longula presented greater stem diameter than the control (Table 2).

Higher activity of soil dehydrogenase occurred in the treatment with $A$. longula (Table 2). Global enzymatic activity was higher in the presence of the nematode ( 0.90 and 0.86 $\mu \mathrm{g}$ of flurescein $\mathrm{g}^{-1}$ dry soil, respectively for treatments with and without nematodes) with the same occurring for $\mathrm{CO}_{2}$ evolution, except for the treatment with $A$. longula (Table 1).

In the absence of the nematode higher rates of respiration 
Table 1. Plantlet growth data, rhizosphere microbial activity and mycorrhizal colonization in roots of guava in the treatments: uninoculated (control) and inoculated with AMF, in the absence $(-)$ or presence $(+)$ of Meloidogyne enterolobii, 98 days after inoculation with AMF, under greenhouse conditions

\begin{tabular}{|c|c|c|c|c|c|c|c|c|c|c|}
\hline \multirow[t]{2}{*}{ Treatment } & \multicolumn{2}{|c|}{ Leaf number } & \multicolumn{2}{|c|}{$\begin{array}{l}\text { Dry biomass of } \\
\text { aerial parts }(\mathrm{g})\end{array}$} & \multicolumn{2}{|c|}{$\begin{array}{c}\mathrm{CO}_{2}\left(\mu \mathrm{g} \mathrm{C}-\mathrm{CO}_{2} / \mathrm{g}\right. \\
\text { dry soil/day) }\end{array}$} & \multicolumn{2}{|c|}{$\begin{array}{c}\text { Arbuscule } \\
\text { colonization (\%) }\end{array}$} & \multicolumn{2}{|c|}{$\begin{array}{c}\text { Total colonization } \\
(\%)\end{array}$} \\
\hline & - & + & - & + & - & + & - & + & - & + \\
\hline Control & $23 \mathrm{aA}$ & $17 \mathrm{bB}$ & $6.59 \mathrm{aA}$ & $7.53 \mathrm{aA}$ & $2.21 \mathrm{abB}$ & $9.26 \mathrm{aA}$ & $10 \mathrm{dA}$ & $14 \mathrm{cA}$ & $42 \mathrm{bA}$ & $23 \mathrm{bA}$ \\
\hline Acaulospora longula & $20 \mathrm{abB}$ & $28 \mathrm{aA}$ & $8.97 \mathrm{aA}$ & $6.99 \mathrm{aA}$ & $4.04 \mathrm{aA}$ & $2.27 \mathrm{cA}$ & $35 \mathrm{bA}$ & $26 \mathrm{bB}$ & $62 \mathrm{aA}$ & $40 \mathrm{abB}$ \\
\hline Gigaspora albida & $26 \mathrm{aA}$ & $18 \mathrm{bB}$ & $7.49 \mathrm{aA}$ & $5.74 \mathrm{abA}$ & $1.57 \mathrm{bB}$ & $5.87 \mathrm{bA}$ & $46 \mathrm{aA}$ & $38 \mathrm{aB}$ & $48 \mathrm{abA}$ & $42 \mathrm{aA}$ \\
\hline Glomus etunicatum & $16 \mathrm{bA}$ & $16 \mathrm{bA}$ & $7.70 \mathrm{aA}$ & $4.05 \mathrm{bB}$ & $0.50 \mathrm{bB}$ & $4.87 \mathrm{bA}$ & $27 \mathrm{cA}$ & $18 \mathrm{bcB}$ & $32 \mathrm{bA}$ & $38 \mathrm{abA}$ \\
\hline
\end{tabular}

Mean values followed by the same lower case letters, in the column, and capital letters in the row, do not differ according to the Tukey test at $5 \%$ probability

in the soil were detected in the treatment with A. longula. For the treatments with nematode, higher rates of respiration were observed in the control (Table 1).

In spite of the attempt to sterilize the soil, the non inoculated control was colonized by AMF. In the treatment without nematodes, $A$. longula produced more colonization than the control, whereas in the presence of the pathogen, this occurred in the treatment with G. albida. The presence of $M$. enterolobii decreased the colonization produced by $A$. longula in the inoculated plants (Table 1).

Arbuscules were the colonization structures more affected by the presence of the nematode. In the absence of $M$. enterolobii, all treatments differed statistically, with inoculated roots presenting more arbuscular colonization than the control. Among the inoculated treatments, that with $G$. albida had more colonized roots, even in the presence of $M$. enterolobii (Table 1). Regardless of the presence of the nematode and compared to the control, colonization by hyphae was greater in roots inoculated with G. albida, whereas more vesicles were formed in roots associated with A. longula (Table 2).

The nematode did not affect glomerospores production and GRSP (glomalin-related soil proteins) (Table 2). G. albida produced more glomerospores than the other AMF and higher glomalin content was observed in the rhizosphere of plants inoculated with this fungus, when compared with the G. etunicatum treatment (Table 2).

The total number of galls, egg masses and eggs did not

Table 2. Plantlet growth variables, dehydrogenase activity, glomalin content, AMF spore density in the rhizosphere and colonization by vesicles and by hyphae in guava roots in the treatments uninoculated (control) and inoculated with AMF, regardless of the inoculation with Meloidogyne enterolobii, 98 days after inoculation with AMF in the greenhouse

\begin{tabular}{lcccccccc}
\hline \hline Treatments & $\begin{array}{c}\text { Diameter } \\
(\mathrm{cm})\end{array}$ & $\begin{array}{c}\text { Fresh root } \\
\text { Biomass } \\
(\mathrm{g})\end{array}$ & $\begin{array}{c}\text { Leaf area } \\
\left(\mathrm{cm}^{2}\right)\end{array}$ & $\begin{array}{c}\text { Dehydrogenase } \\
(\mu \mathrm{g} \text { TTF } \\
/ \mathrm{g} \text { dry soil })\end{array}$ & $\begin{array}{c}\text { Glomalin } \\
(\mathrm{mg} \text { glomalin } \\
\text { /g soil })\end{array}$ & $\begin{array}{c}\text { Spore } \\
\text { density } \\
(50 / \mathrm{g} \text { soil })\end{array}$ & $\begin{array}{c}\text { Colonization Colonization } \\
\text { by vesicles } \\
(\%)\end{array}$ & $\begin{array}{c}\text { Cy hyphae } \\
(\%)\end{array}$ \\
\hline Control & $0.438 \mathrm{~b}$ & $5.17 \mathrm{~b}$ & $445.27 \mathrm{~b}$ & $0.043 \mathrm{~b}$ & $1.034 \mathrm{ab}$ & $0.3 \mathrm{~d}$ & $0.14 \mathrm{~b}$ & $3.2 \mathrm{~b}$ \\
Acaulospora longula & $0.585 \mathrm{a}$ & $10.46 \mathrm{a}$ & $708.77 \mathrm{a}$ & $0.062 \mathrm{a}$ & $1.024 \mathrm{ab}$ & $1.8 \mathrm{c}$ & $0.92 \mathrm{a}$ & $3.4 \mathrm{~b}$ \\
Gigaspora albida & $0.521 \mathrm{ab}$ & $11.75 \mathrm{a}$ & $677.94 \mathrm{a}$ & $0.033 \mathrm{~b}$ & $1.185 \mathrm{a}$ & $46.8 \mathrm{a}$ & $0.00 \mathrm{~b}$ & $49.0 \mathrm{a}$ \\
Glomus etunicatum & $0.508 \mathrm{ab}$ & $9.21 \mathrm{a}$ & $497.25 \mathrm{~b}$ & $0.037 \mathrm{~b}$ & $0.929 \mathrm{~b}$ & $10.8 \mathrm{~b}$ & $0.26 \mathrm{ab}$ & $11.0 \mathrm{~b}$ \\
\hline
\end{tabular}

Mean values followed by the same letter in the column do not differ according to the Tukey test at $5 \%$ probability

Table 3. Variables related to the nematode (Meloidogyne enterolobii) in roots of guava plants, with or without AMF, 98 days after inoculation with the fungi, and maintained in a greenhouse

\begin{tabular}{lcccccc}
\hline \hline Treatments & $\begin{array}{c}\text { Number of } \\
\text { galls } \\
\text { (total) }\end{array}$ & $\begin{array}{c}\text { Number of } \\
\text { galls } \\
\text { (/g root) }\end{array}$ & $\begin{array}{c}\text { Number of egg } \\
\text { masses } \\
\text { (total) }\end{array}$ & $\begin{array}{c}\text { Number of egg } \\
\text { masses } \\
\text { (/g root) }\end{array}$ & $\begin{array}{c}\text { Number of } \\
\text { eggs } \\
\text { (total) }\end{array}$ & $\begin{array}{c}\text { Number of } \\
\text { eggs } \\
(/ g \text { root) }\end{array}$ \\
\hline Control & $207.2 \mathrm{a}$ & $32.4 \mathrm{a}$ & $169.0 \mathrm{a}$ & $30.2 \mathrm{a}$ & $44.524 \mathrm{a}$ & $7.093 \mathrm{a}$ \\
Acaulospora longula & $181.4 \mathrm{a}$ & $15.0 \mathrm{~b}$ & $85.4 \mathrm{a}$ & $11.6 \mathrm{~b}$ & $17.671 \mathrm{a}$ & $1.658 \mathrm{~b}$ \\
Gigaspora albida & $175.2 \mathrm{a}$ & $28.8 \mathrm{a}$ & $128.6 \mathrm{a}$ & $19.2 \mathrm{ab}$ & $38.478 \mathrm{a}$ & $5.362 \mathrm{a}$ \\
Glomus etunicatum & $285.8 \mathrm{a}$ & $46.0 \mathrm{a}$ & $88.0 \mathrm{a}$ & $20.6 \mathrm{ab}$ & $6.455 \mathrm{a}$ & $1.246 \mathrm{~b}$ \\
\hline
\end{tabular}

Mean values followed by the same letter in the column do not differ according to the Tukey test at $5 \%$ probability. 
significantly differ but when the quantities per gram of root were considered, the treatments with $A$. longula had lower amounts, and that with G. etunicatum also presented a lower number of eggs, compared to the control (Table 3).

\section{Discussion}

Significant interactions were found between AMF and $M$. enterolobii in number of leaves, dry biomass of aerial plantlet parts. This was also true for total mycorrhizal colonization, arbuscules and $\mathrm{CO}_{2}$ evolution in the soil. The leaf area differed significantly in the nematode treatments or with AMF, but there was no interaction. Stem diameter and fresh root biomass, soil dehydrogenase activity, GRSP, AMF spore density and mycorrhizal colonization by hyphae and vesicles were affected only by the AMF treatments, whereas for the global enzymatic activity of the soil, a significant effect was only observed for the nematode.

Inside the roots, the root-knot nematodes (Meloidogyne spp.) create a feeding site deriving continuous nourishment from adjacent cells and producing galls that affect the plant's metabolism and resource allocation, impairing the absorption and transport of water and nutrients which results in decreased plant development (Borowicz, 2001; Carneiro et al., 2002). The presence of AMF, which compete for space and nutrients with the nematode, may reduce this effect, inducing plant development even in the presence of the pathogen, as observed in olive plants (Olea europaea L.) (Castillo et al., 2006), alpinia [Alpinia purpurata (Viell.) Schum] (Silva, 2005), papaya (Carica papaya L.) (JaizmeVega et al., 2006), sweet passion fruit (Passiflora alata Curtis) (Anjos et al., 2010) and other crops.

Different AMF can induce various responses in Meloidogyne infected plants, and the response of a plant species varies considerably with the identity of the symbiotic fungus (Smith et al., 2009). In tomatoes (Lycopersicon esculentum L.) infected with Meloidogyne javanica (Treub) Chitwood associated with Gigaspora margarita W. N. Becker \& I. R. Hall the biomass of the aerial part, weight and number of fruits were similar to the control, while in presence of Glomus etunicatum these parameters were increased (Cofcewicz et al., 2001).

Guava plants associated with G. albida and A. longula presented greater growth than the other treatments. Despite the fact that there is no specificity between AMF and their hosts, greater compatibility can occur between some species of AMF and plants, and differences can be attributed to the genotype and the functional compatibility of the partners (Costa et al., 2001). Thus, AMF selection is very important for the establishment of an effective symbiosis. The literature presents an example showing that growth of sweet passion-fruit plantlets was more improved by inoculation with G. albida than with G. etunicatum or A. longula (Silva et al., 2004). Also, inoculation with G. margarita and Glomus intraradices N. C. Schenck \& G. S. Sm. enhanced biomass production of strawberry plantlets (Fragaria ananassa Duch.), whereas growth was impaired by other seven AMF species (Taylor and Harrier, 2001).

Higher activity of soil dehydrogenase in the treatment with A. longula may indicate higher production of hyphae by this fungus than by the other AMF, as detected by the dehydrogenase activity, considering that it reflects the oxidative potential of the soil (Gianfreda et al., 2005).

Nematode respiration may have contributed to greater metabolic activity and these organisms, as well as the roots they damage, are sources of organic matter, favoring respiratory and enzymatic activity of soil organisms, as reported by Fernandes et al. (2005). Plant parasite nematodes increase organic carbon availability in the soil and consequently microbial activity and $\mathrm{CO}_{2}$ release (Tu et al., 2003); this fact occurs when the nematode perforates the root cell, leaving a hole through which carbon is drained and can be easily used by the microbial community. Plant nematodes may also facilitate the decomposition of organic matter due to partial degradation of cellulose considering that their enzymes break down this compound (Tu et al., 2003).

In the absence of the nematode higher rates of respiration in the soil were detected in the treatment with A. longula, confirming the results related with dehydrogenase activity and reinforcing the possibility of the presence of more hyphae of this fungus. For the treatments with nematode, higher rates of respiration were registered in the control, which could be related to the reduction of the nematodes population induced by the AMF and consequently, less respiration. Among the fungi, Acaulospora longula and $G$. etunicatum were more promising than G. albida in inducing a decrease in the population of nematodes in the roots, as shown by the number of galls, egg masses and eggs.

The intensity of mycorrhizal colonization can be affected by the presence of nematodes and varies according to the AMF species. In the rhizosphere of Cucumis sativus L. cv. Zhongnong 16 the presence of Meloidogyne incognita (Kofoid \& White) Chitwood decreased colonization by Glomus mosseae (T. H. Nicolson \& Gerd.) Gerd. \& Trappe whereas colonization by $G$. intraradices was not affected by the nematode (Zhang et al., 2008). In white clover (Trifolium repens L.), M. incognita induced an increase in colonization by $G$ intraradices, without any effect in the colonization produced by G. aggregatum N. C. Schenck \& G. S. Sm. and G. mosseae (Habte et al., 1999). From a meta-analysis including 90 experiments, Borowicz (2001) observed that presence of nematodes reduced AMF colonization in only $16 \%$ of them.

A correlation between the amount of glomerospores and 
glomalin has been reported (Bedini et al., 2007), since this glycoprotein is one of the constituents of the spore wall, but this was not observed in this work.

The treatment with G. etunicatum presented a lower number of eggs, compared to the control. This can be related to the effects of the fungus on the development of the nematode, which penetration into the roots was high, inducing gall formation, but reproduction was low (number of eggs). A decrease in the body length of nematodes (M. javanica) and a smaller number of giant cells were reported in tomato plants infected by this pathogen and associated with $G$. mosseae (Siddiqui and Mahmood, 1998).

Considering that in plants associated with $A$. longula there was less penetration of the nematode and a lower reproduction rate (eggs per gram of root), the effects would be from the AMF pre-colonization, making the roots less attractive to the nematode. Therefore, some physiological alterations probably promoted by the AMF, such as modification of the chemical composition of root exudates and production of some compounds (phenylalanine, serine, phenols), may have an antagonistic effect toward the nematodes, as observed in other studies (Siddiqui and Mahmood, 1995). The reduction in penetration may also be due to changes in cell wall composition of the roots ( Hol and Cook, 2005), as well as by the activation of plant defense mechanisms stimulated by the AMF (Azcón-Aguilar and Barea, 1996). Vos et al. (2011) observed less juveniles penetration in mycorrhizal roots of the Solanum lycopersicum L. cv. Marmande.

The effects of inoculation with AMF on the development and reproduction of nematodes depend on the fungus and plant species involved (Carling et al., 1996). In peanuts (Arachis hypogaea) the presence of G. etunicatum increased the number of galls in the roots and the production of eggs by Meloidogyne arenaria (Neal) Chitwood (Carling et al., 1996). The opposite occurred in Musa AAA cv. Grande Naine infected with $M$. incognita and inoculated with $G$. mosseae (Jaizme-Vega et al., 1997). However, in Lycopersicon esculentum L. cv. Tounvi the number of galls in the roots decreased, while the number of eggs increased in the treatments with G. mosseae or Acaulospora spinosa C. Walker \& Trappe (Affokpon et al., 2011). The mechanisms involved in the AMF root knot nematode relationship and the effect of the host plant on both organisms are still not clear (Azcón-Aguilar and Barea, 1996); therefore, studies that elucidate this mode of action are very important in order to promote the biocontrol of these pathogens.

The effects of AMF on the growth of plants inoculated with Meloidogyne spp. are highly variable, but usually positive; the same occurring in regard to the establishment of the symbiosis and development of the nematode (Maia et al., 2006). Among the AMF treatments, that with A. longula was the most promising because it not only induced a reduction in the amount of $M$. enterolobii eggs, but also was efficient in increasing plant growth. In the treatment with $G$. etunicatum, there was a decrease in the number of nematode eggs but no benefits for plant development and in plants associated with G. albida, no growth benefits or decrease in number of eggs were observed. In experiments with $A$. purpurata inoculation with the same isolate of $A$. longula used in this study, increased plant growth was observed, even in the presence of $M$. arenaria, with a decrease in the number of eggs (Silva, 2005), demonstrating the efficiency of this fungus in controlling root-knot nematodes. Thus, strategies for establishment of plantlets in the field and increase in the production of guava, even in the presence of nematodes, should include more studies with $A$. longula and other species, for selection of promising isolates that can be used in association with guava plants in semi-arid regions.

\section{Acknowledgements}

We thank the Conselho Nacional de Desenvolvimento Científico (CNPq) for financial support and fellowships to L. C. Maia (PQ) and A. M. Yano-Melo (PQ) and a scholarship to M. A. S. Campos (DO). Thanks are also due to Dr. Romero Moura for reading the manuscript and making valuable suggestions. The Biotechnology Laboratory at the Embrapa Semi-Arid Station is acknowledged for providing logistical support.

\section{References}

Affokpon, A., Coyne, D. L., Lawouin, L., Tossou, C., Agbèd, R. D. and Coosemans, J. 2011. Effectiveness of native West African arbuscular mycorrhizal fungi in protecting vegetable crops against root- knot nematode. Biol. Fertil. Soils 47:207-217.

Anjos, E. C. T., Cavalcante, U. M. T., Gonçalves, D. M. C., Pedrosa, E. M. R., Santos, V. F. and Maia, L. C. 2010. Interactions between an arbuscular mycorrhizal fungus (Scutellospora heterogama) and the root-knot nematode (Meloidogyne incognita) on sweet passion fruit (Passiflora alata). Braz. Arch. Biol. Technol. 53:801-809.

Azcón-Aguilar, C. and Barea, J. M. 1996. Arbuscular mycorrhizas and biological control of soil-borne plant pathogens - an overview of the mechanisms involved. Mycorrhiza 6:457464.

Bedini, S., Avio, L., Argese, E. and Giovannetti, M. 2007. Effects of long-term land use on arbuscular mycorrhizal fungi and glomalin-related soil protein. Agr. Ecosyst. Environ. 120:463466.

Borowicz, V. A. 2001. Do arbuscular mycorrhizal fungi alter plant-pathogen relations? Ecology 82:3057-3068.

Bradford, M. M. 1976. A rapid and sensitive method for the quantification of microgram quantities of protein utilizing the prin- 
ciple of protein-dye binding. Anal. Biochem. 72:248-254.

Brundrett, M. C., Pich, Y. and Peterson, R. L. 1984. A new method for observing the morphology of vesicular-arbuscular mycorrhizae. Can. J. Bot. 62:2128-2134.

Carling, D. E., Roncadori, R. W. and Hussey, R. S. 1996. Interactions of arbuscular mycorrhizae Meloidogyne arenaria, and phosphorus fertilization on peanut. Mycorrhiza 6:9-13.

Carneiro, R. M. D. G., Moreira, W. A., Almeida, M. R. A. and Gomes, A. C. M. M. 2001. Primeiro registro de Meloidogyne mayaguensis em goiabeira no Brasil. Nematol. Bras. 25:223228.

Carneiro, R. G., Mazzafera, P., Ferraz, L. C. C. B., Muraoka, T. and Trivelin, P. C. O. 2002. Uptake and translocation of nitrogen, phosphorus and calcium in soybean infected with Meloidogyne incognita and M. javanica. Fitopatol. Bras. 27: 141-150.

Casida, L. E., Klein, D. and Santoro, T. 1964. Soil dehydrogenase. Soil Sci. 98:371-376.

Castillo, P., Nico, A. I., Azcón-Aguilar, C., del Río Rincón, C., Calvet, C. and Jiménez-Diaz, R. M. 2006. Protection of olive planting stocks against parasitism of root-knot nematodes by arbuscular mycorrhizal fungi. Plant Pathol. 55:705-713.

Cofcewicz, E. T., Medeiro, C. A. B., Carneiro, R. M. D. G. and Pierobom, C. R. 2001. Interação dos fungos micorrízicos arbusculares Glomus etunicatum e Gigaspora margarita e o nematóide das galhas Meloidogyne javanica em tomateiro. Fitopatol. Bras. 26:65-70.

Costa, C. M. C., Maia, L. C., Cavalcante, U. M. T. and Nogueira, R. J. M. C. 2001. Influência de fungos micorrízicos arbusculares sobre o crescimento de dois genótipos de aceroleira (Malpighia emarginata D. C.). Pesqui. Agropecu. Bras. 36:893901.

Diedhiou, P. M., Hallmann, J., Oerke, E. C. and Dehne, H. W. 2003. Effects of arbuscular mycorrhizal fungi and a nonpathogenic Fusarium oxysporum on Meloidoyne incognita infestation of tomato. Mycorrhiza 13:199-204.

Elsen, A., Baimey, H., Swennen, R. and De Waele, D. 2003. Relative mycorrhizal dependency and mycorrhiza-nematode interaction in banana cultivars (Musa spp.) differing in nematode susceptibility. Plant Soil 256:303-313.

Fernandes, S. A. P., Bettiol, W. and Cerri, C. C. 2005. Effect of sewage sludge on microbial biomass, basal respiration, metabolic quotient and soil enzymatic activity. Appl. Soil Ecol. 30:65-77.

Gerdemann, J. W. and Nicolson, T. H. 1963. Spores of mycorrizal endogone species extracted from soil by wet sieving and decanting. T. Brit. Mycol. Soc. 46:235-244.

Gianfreda, L., Rao, M. A., Piotrowska, A., Palumbo, G. and Colombo, C. 2005. Soil enzyme activities as affected by anthropogenic alterations: intensive agricultural practices and organic pollution. Sci. Total Environ. 341:265-279.

Grisi, B. M. 1978. Método químico de medição da respiração edáfica: alguns aspectos técnicos. Cien. Cul. 30:82-88.

Habte, M., Zhang, Y. C. and Schmitt, D. P. 1999. Effectiveness of Glomus species in protecting white clover against nematode damage. Can. J. Bot. 77:135-139.
Hol, W. H. G. and Cook, R. 2005. An overview of arbuscular mycorrhizal fungi-nematode interactions. Basic Appl. Ecol. 6:489-503.

Hussey, R. S. and Barker, K. R. 1973. A comparison of methods of collecting inocula of Meloidogyne spp., including a new technique. Plant Dis. Rep. 57:1025-1028.

Jaizme-Vega, M. C., Tenoury, P., Pinochet, J. and Jaumot, M. 1997. Interactions between the root-knot nematode Meloidogyne incognita and Glomus mosseae in banana. Plant Soil 196:27-35.

Jaizme-Vega, M. C., Rodriguez- Romero, A. S. and Núnez, L. A. B. 2006. Effect of the combined inoculation of arbuscular mycorrhizal fungi and plant growth-promoting rhizobacteria on papaya (Carica papaya L.) infected with the root-knot nematode Meloidogyne incognita. Fruits 61:151-162.

Jenkins, W. R. 1964. A rapid centrifugal flotation technique for separating nematodes from soil. Plant Dis. Rep. 48:692.

Maia, L. C., Silveira, N. S. S. and Cavalcante, U. M. T. 2006. Interaction between arbuscular mycorrhizal fungi and root pathogens. In: Handbook of Microbial Biofertilizers, ed. by M. K. Rai, pp. 325-351. New Delhi: The Haworth Press.

McGonigle, T. P., Miller, M. H., Evans, D. G., Fairchild, G. L. and Swan, J. A. 1990. A new method which gives an objective measure of colonization of roots by vesicular-arbuscular mycorrhizal fungi. New Phytol. 115:495-501.

Schiavo, J. A. and Martins, M. A. 2002. Produção de mudas de goiabeira (Psidium guajava L.) inoculadas com o fungo micorrízico arbuscular Glomus clarum, em substrato agroindustrial. Rev. Bras. Frutic. 24:519-523.

Siddiqui, Z. A. and Mahmood, I. 1995. Role of plant symbionts in nematode management: a review. Bioresource Technol. 54: 217-226.

Siddiqui, Z. A. and Mahmood, I. 1998. Effect of a plant growth promoting bacterium, an AM fungus and soil types on the morphometrics and reproduction of Meloidogyne javanica on tomato. Appl. Soil Ecol. 8:77-84.

Silva, M. A., Cavalcante, U. M. T., Silva, F. S. B., Soares, S. A. G. and Maia, L. C. 2004. Crescimento de mudas de maracujazeiro-doce (Passiflora alata Curtis) associadas a fungos micorrízicos arbusculares (Glomeromycota). Acta Bot. Bras. 18:981-985.

Silva, M. A. 2005. Aplicação de fungos micorrízicos arbusculares (FMA) na aclimatização de duas plantas ornamentais tropicais micropropagadas, visando tolerância ao parasitismo de Meloidogyne arenaria. Dissertação. Universidade Federal de Pernambuco, Brasil.

Smith, S. E., Facelli, E., Pope, S. and Smith, F. A. 2009. Plant performance in stressful environments: interpreting new and established knowledge of the roles of arbuscular mycorrhizas. Plant Soil 326:3-20.

Statsoft. 1997. Statistica for Windows. Tulsa (CD-ROM).

Swisher, R. and Carrol, G. C. 1982. Fluorescein diacetate hydrolysisas an estimator of microbial biomass on coniferous needle surfaces. Microbial Ecol. 6:217-226.

Taylor, J. and Harrier, L. A. 2001. A comparison of development and mineral nutrition of micropropagated Fragaria $\times$ anan- 
assa cv. Elvira (strawberry) when colonized by nine species of arbuscular mycorrhizal fungi. Appl. Soil Ecol. 18:205-215.

Tu, C., Koenning, S. R. and Hu, S. 2003. Root-parasitic nematodes enhance soil microbial activities and nitrogen mineralization. Microbial Ecol. 46:134-144.

Vos, C., Geerinckx, K., Mkandawire, R., Panis, B., De Waele, D. and Elsen, A. 2012. Arbuscular mycorrhizal fungi affect both penetration and further life stage development of root-knot nematodes in tomato. Mycorrhiza 22:157-163.

Wright, S. F. and Upadhyaya. 1996. A Extraction of an abundant and unusual protein from soil and comparison on hyphal protein of arbuscular mycorrhizal fungi. Soil Sci. 161:575-586.

Zhang, L., Zhang, J., Christie, P. and Li, X. 2008. Pre-inoculation with arbuscular mycorrhizal fungi suppresses root knot nematode (Meloidogyne incognita) on cucumber (Cucumis sativus). Biol. Fert. Soil 45:205-211. 